\title{
Measuring Root Disease Suppression in Response to a Compost Water Extract
}

\author{
Gilberto Curlango-Rivera, Tom Pew, Hans D. VanEtten, Xiong Zhongguo, Naitong Yu, and Martha C. Hawes
}

First and sixth authors: Soil, Water and Environmental Sciences Department, University of Arizona; second author: Merlin Organics, 5445 N. Camino Escuela, Tucson, AZ 85718; third and fourth authors: School of Plant Sciences and BIO5 Institute, University of Arizona; and fifth author: School of Plant Sciences and BIO5 Institute, University of Arizona, and Ministry of Agriculture Key Laboratory for Tropical Crop Biotechnology, Institute of Tropical Bioscience and Biotechnology, Chinese Academy of Tropical Agricultural Science, Haikou, Hainan 571101, P. R. China.

Accepted for publication 6 November 2012.

\begin{abstract}
Curlango-Rivera, G., Pew, T., VanEtten, H. D., Zhongguo, X., Yu, N., and Hawes, M. C. 2013. Measuring root disease suppression in response to a compost water extract. Phytopathology 103:255-260.

Commercial application of compost to prevent plant disease is hindered by variable performance. Here, we describe the use of a growth pouch assay to measure impact of a compost water extract (CWE) on root infection under controlled conditions. Most pea roots $(\geq 95 \%)$ inoculated with Fusarium solani or Phoma pinodella spores rapidly develop a single local lesion in the region of elongation. In the presence of CWE, infection of pea roots grown in pouches was reduced by 93 to $100 \%$. CWE used as

but, in a heavy clay soil, infection was reduced by $<50 \%$. CWE filtered to remove microorganisms did not inhibit frequency of $F$. solani infection, and resulted in increased local lesion development on individual roots. CWE inhibited mycelial growth of both pea- and cucumber-infecting isolates of $F$. solani in culture but exerted $<40 \%$ protection against cucumber root infection. CWE treatment of pea but not cucumber was associated with retention of a sheath of border cells interspersed with bacteria covering the region of elongation. Growth pouch assays may provide a system to monitor effects of specific compost mixtures on rootrhizosphere interactions, and to identify variables influencing disease control.
\end{abstract} a drench on pea seedlings grown in sand also resulted in $100 \%$ protection
In recent decades, global interest in sustainable agriculture increasingly has focused on reduced reliance on commercial fertilizers and pesticides $(25,26,33)$. Urgency in developing biological control methods for soilborne diseases has increased as efforts to cease application of methyl bromide have progressed $(14,16)$. Compost in various forms has been used for centuries but concerns about food safety, reproducibility, and phytotoxicity have hampered systematic application of such approaches in agriculture $(4,13,29,38)$. The United States Department of Agriculture has outlined a critical need to define, measure, and determine mechanisms of compost function in plant health and development in diverse climate and soil environments (USDA.gov). Although chemically defined pesticides and fertilizers can predictably influence crop production, composts are heterogeneous mixtures whose intrinsic variability complicates efforts to achieve reproducible results. Defining biological control mechanisms even with specific microbial populations under controlled conditions remains a longstanding challenge (24). Defining mode of action for any given solid compost preparation sufficiently to predict efficacy for a given crop may not be a realistic goal. Water extracts of compost, by contrast, yield a liquid product that is amenable to chemical and biological analysis, and can be applied as a drench to plant surfaces $(9,20,34,43)$. Promising effects of compost treatments on important soilborne pathogens, including species of Pythium (5,8,35), Phytophthora (31), Fusarium (12,23,32), Rhizoctonia (35), and Meloidogyne (43), reveal the benefits to be gained by a

Corresponding author: M. C. Hawes; E-mail address: mhawes@u.arizona.edu

* The $e$-Xtra logo stands for "electronic extra" and indicates that the online version contains two supplemental tables.

http://dx.doi.org/10.1094/PHYTO-06-12-0145-R

(c) 2013 The American Phytopathological Society better understanding of how disease is reduced with some crop species in some conditions.

Little is known about physiological effects of compost during early root development. Root tips $(\approx 1$ to $2 \mathrm{~cm}$ from the apex) of higher plants contain primary sites for the establishment of beneficial and pathogenic root-microbe associations and can influence the architecture of the entire plant $(1,10,36)$. Therefore, understanding how compost influences root tip and rhizosphere structure and function may be critical to designing reliable approaches to crop improvement. Unfortunately, the fact that roots grow underground, out of sight, is an obstacle to evaluating the dynamic cellular and biochemical bases for root tip responses to additives (11). A rapid, cost-effective growth pouch assay has been used for decades to describe mechanisms of root infection and colonization by Rhizobium spp. and other bacteria, including species isolated from compost mixtures $(2,19)$. Clapp and coworkers (7) introduced the growth pouch assay as a tool to quantify plant responses to soluble nutritional factors from humic substances commonly used in compost preparations. We have used the pouch assay to document mechanisms by which root border cell populations released from root caps function in defense $(17,21,22)$. In the current study, we report effects of a specific compost water extract (CWE) on susceptibility of roots to fungal infection, using the soilborne pathogen Fusarium solani f. sp. pisi (Nectria haematococca mating population VI) and its host, Pisum sativum L., as the primary model system.

\section{MATERIALS AND METHODS}

Plant material. Pea ( $P$. sativum L.) seed of 'Little Marvel' (Meyer Quality Seeds, Baltimore, MD) and 'Alaska' (Chesmore Seed Company, St. Joseph MO) were treated as described previously $(17,18)$. After immersion for $10 \mathrm{~min}$ in $95 \%$ ethanol fol- 
lowed by 60 min in $5.0 \%$ sodium hypochlorite, seeds were rinsed six times in distilled water and then imbibed in sterilized water for $6 \mathrm{~h}$. Seeds that floated to the surface were discarded. Imbibed seeds were placed on $1 \%$ water agar overlaid with germination paper, then incubated for $48 \mathrm{~h}$ at $24^{\circ} \mathrm{C}$ in the dark. Maize (Zea mays L., 'Golden Cross Bantam') (Ferry-Morse Seed Company, Fulton KY) seeds were treated for 5 min in $95 \%$ ethanol followed by $10 \mathrm{~min}$ in $2.5 \%$ sodium hypochlorite, then rinsed six times in distilled water. Cucumber (Cucumis sativa L.) (Ferry-Morse Seeds) seeds were treated for $5 \mathrm{~min}$ in $95 \%$ ethanol followed by $5 \mathrm{~min}$ in $2.5 \%$ sodium hypochlorite, then rinsed six times in distilled water. Seedlings were used when roots were 20 to $25 \mathrm{~mm}$ in length.

Pathogen isolates. Many species share the anamorph name $F$. solani but, within the $F$. solani complex, there are seven distinct heterothallic groups called mating populations (MPs) that act as biological species (30). These isolates have been called by their teleomorph $N$. haematococca, and what is called $F$. solani in this article refers to $N$. haematococca. $F$. solani $\mathrm{f}$. sp. pisi, pathogenic on pea; $F$. solani f. sp. cucurbitacae (N. haematococca MPI), pathogenic on cucurbits; and Phoma pinodella (L. K. Jones), T409 cultures were maintained and processed as described previously $(17,18)$.

CWE preparation. A fresh batch of compost was prepared for each experiment, and experiments reported here reflect results from 22 independent batches produced over a 2-year period (April 2010 to April 2012). A 18.9-liter brewer (www.simplicitea.com) was filled with well water. The following ingredients were added, and the mixture was maintained at $26^{\circ} \mathrm{C}$ for $18 \mathrm{~h}$, $40 \mathrm{~min}$ : $250 \mathrm{ml}$ of Alaskan humus (Earthfort; www.earthfort.com/), $250 \mathrm{ml}$ of worm castings (Acme Worm Farm, Tucson AZ), $15 \mathrm{ml}$ of rock phosphate dust (Peaceful Valley; www.groworganic.com), $57 \mathrm{~g}$ of fish hydrolysate (Earthfort), $28 \mathrm{~g}$ of Algamin (Cold Processed Kelp; Peaceful Valley), $28 \mathrm{~g}$ of organic Turf Pro

TABLE 1. Impact of compost water extract (CWE) on infection of pea roots by Fusarium solani and Phoma pinodella

\begin{tabular}{|c|c|c|c|}
\hline \multirow[b]{2}{*}{ Treatment $^{\mathrm{Z}}$} & \multicolumn{2}{|c|}{ Number of seedlings } & \multirow[b]{2}{*}{ Infected (\%) } \\
\hline & Noninfected & Infected & \\
\hline \multicolumn{4}{|l|}{ Growth pouch } \\
\hline \multicolumn{4}{|l|}{ ‘Alaska' pea } \\
\hline Water & 129 & 0 & $0 \mathrm{a}$ \\
\hline CWE & 124 & 0 & $0 \mathrm{a}$ \\
\hline F. solani & 2 & 127 & $98 \mathrm{~b}$ \\
\hline CWE + F. solani & 121 & 3 & $2 \mathrm{a}$ \\
\hline \multicolumn{4}{|l|}{ 'Little Marvel' pea } \\
\hline Water & 30 & 0 & $0 \mathrm{a}$ \\
\hline CWE & 30 & 0 & $0 \mathrm{a}$ \\
\hline F. solani & 2 & 28 & $93 \mathrm{~b}$ \\
\hline CWE + F. solani & 30 & 0 & $0 \mathrm{a}$ \\
\hline \multicolumn{4}{|l|}{ 'Alaska' pea } \\
\hline Water & 10 & 0 & $0 \mathrm{a}$ \\
\hline CWE & 10 & 0 & $0 \mathrm{a}$ \\
\hline P. pinodella & 0 & 10 & $100 \mathrm{~b}$ \\
\hline CWE $+P$. pinodella & 9 & 1 & $10 \mathrm{a}$ \\
\hline \multicolumn{4}{|l|}{ Sand ('Alaska' pea) } \\
\hline Water & 40 & 0 & $0 \mathrm{a}$ \\
\hline CWE & 40 & 0 & $0 \mathrm{a}$ \\
\hline F. solani & 0 & 40 & $100 \mathrm{~b}$ \\
\hline CWE + F. solani & 40 & 0 & $0 \mathrm{a}$ \\
\hline \multicolumn{4}{|l|}{ Soil ('Alaska' pea) } \\
\hline Water & 20 & 0 & $0 \mathrm{a}$ \\
\hline CWE & 20 & 0 & $0 \mathrm{a}$ \\
\hline F. solani & 0 & 20 & $100 \mathrm{~b}$ \\
\hline $\mathrm{CWE}+$ F. solani & 11 & 9 & $45 \mathrm{c}$ \\
\hline
\end{tabular}

y Values reflect results from at least 10 replicate samples for each treatment. Percentages of infection with the same letter are not significantly different according to Fisher's exact test $(P<0.05)$. Plants grown in sand or soil were monitored for 4 weeks after inoculation.

${ }^{\mathrm{z}} \mathrm{CWE}=$ compost water extract.
(Earthfort); and $15 \mathrm{ml}$ of Compost Tea Catalyst (Peaceful Valley). The presence of a mixed population of bacteria, fungi, and protozoa was confirmed by direct microscopic examination of representative samples, and $\mathrm{pH}(5.2 \pm 0.6)$ was measured prior to application. Filtered samples were obtained by sequential passage of CWE samples through Whatman 52 filter paper, a Nalgene $0.45-\mu \mathrm{m}$ syringe filter, and an Acrodisc $0.2-\mu \mathrm{m}$ syringe filter.

Root growth and infection assays. For each set of experiments, a 15-ml sample of water or CWE was placed into the bottom of a growth pouch (Mega International, St. Paul, MN) using a syringe. Five seedlings were placed into each pouch, and roots were inoculated uniformly from base to tip with a $0.2-\mathrm{ml}$ spore suspension $\left(10^{6}\right.$ spores $\left./ \mathrm{ml}\right)$ and left in a horizontal position for $15 \mathrm{~min}$. The position of each root tip was marked on the cellophane pouch at the time the experiment was initiated. Pouches then were maintained at $24^{\circ} \mathrm{C}$, in an upright position, for up to 28 days. Shoot and root growth, morphology, and lesion development over time were measured nondestructively by direct observation. All values represent at least 30 replicates (five seedlings per pouch) in at least three independent experiments, unless otherwise indicated. Lesion development and localization on seedlings grown in pouches and in pots with sand or soil were documented based on the presence of a tan, brown, or black section of root with internal fungal hyphae, as described (17). Pot experiments were monitored over a 4 -week period after inoculation; roots were removed for inspection when aboveground symptoms developed (wilt and chlorosis) or at the end of the 4-week period. Numbers of healthy versus infected seedlings were analyzed by contingency tables, performing Fisher's exact tests using IBM SPSS Statistics for Windows (version 20.0; IBM Corp., Armonk, NY) Fisher's exact test for pairwise comparison analysis between treatments was performed using JMP (version 10; SAS Institute Inc., Cary, NC).

Fungal growth assays. A radial growth inhibition assay was used to measure fungal growth in the presence of CWE or filtered CWE, as described (43). Mycelial plugs were placed at one edge of 35-mm plates containing $1 \mathrm{ml}$ of Martin's peptone-glucose agar medium (28) mixed with 200 or $300 \mu \mathrm{l}$ of CWE or filtered CWE, and the diameter of hyphal extension was measured. Values represent means and standard deviations from three replicate plates in two independent experiments.

Identification of predominant culturable species on roots exposed to CWE. Roots with extended border cell sheaths were agitated in water to disperse microbial populations, and dilution plating was used to isolate predominant species. Single-colony isolates were subjected to rDNA analysis. Total DNA was extracted as described (42). Bacterial 16S rDNA was amplified from the purified DNA using Denville Taq DNA polymerase (Fisher Scientific, Pittsburgh, PA) and primers 10F and 1507R and subjected to a two-stage polymerase chain reaction, as described (41). The partial 16S rDNA sequences were assembled for each bacterial isolate from two overlapping sequences and used to identify sequences with highest identities among the National Center for Biotechnology GenBank.

\section{RESULTS}

Inhibition of pea root infection in growth pouches with CWE. When inoculated with $F$. solani spores, $\geq 93 \%$ of Little Marvel and Alaska pea roots developed visible lesions within $24 \mathrm{~h}$ (Table 1). Despite uniform inoculation of spores over the entire root surface, the initiation of infection was localized to the site which was the region of elongation at the time of inoculation, and lesions remained localized to this $\approx 1-\mathrm{cm}$ section of root (Fig. 1A and B) (1). As described in previous studies $(17,18)$, in most inoculated roots $(>90 \%)$, the apical region $(\approx 0.5 \mathrm{~cm}$ from the apex) housing the root cap and apical meristems escaped infection despite the presence of the pathogen within adjacent tissue. In the 
absence of damage to the meristems, root growth continued in parallel with control roots despite the localized infection. New infections did not develop sequentially within new regions of elongation as they emerged, presumably due to activation of a systemic resistance response by the initial infection (17). In roots in which the meristem region was invaded (Fig. 1B, white arrow), root growth ceased within 16 to $24 \mathrm{~h}$ after infection.

In control samples, in the presence of CWE alone, no obvious phenotypic changes were evident in pea seedlings (Fig. 1C). However, development of lesions on inoculated seedlings of both tested cultivars was reduced from $\geq 93$ to $2 \%$; no significant differences between cultivars was observed. A similar reduction in frequency of infection, from 100 to $10 \%$, occurred in CWEtreated seedlings inoculated with $P$. pinodella (Table 1 ). The protection was retained over a 4 -week period in moist growth pouches maintained at $25^{\circ} \mathrm{C}$, conditions highly favorable to disease development in pea (Table 1; Fig. 2D).

CWE used as a drench for roots of pea seedlings grown in sand, as in growth pouches, resulted in $100 \%$ protection (Table 1). Whereas $100 \%$ of Alaska seedlings inoculated with F. solani developed lesions, no infections occurred in seedlings treated with CWE at the time of inoculation, for up to 4 weeks after inoculation. When CWE was used as a drench for seedlings grown in a heavy clay soil, partial protection occurred in response to CWE (Table 1). Whereas $100 \%$ of inoculated seedlings developed root infections and ceased growth within 3 weeks in the absence of CWE, 45\% developed infection in roots of seedlings drenched with CWE at planting.

Root growth and development in the presence of CWE. One explanation to account for the inhibition of root infection is that CWE contains nutrients or growth stimulants triggering changes in plant development that alter the normal coordination of spore germination and root susceptibility to infection. If so, then altered morphology and growth rate could be predicted to occur in pea and other species treated with CWE. This was tested by measuring rate of root growth, fresh weight, and lateral root development in pea, corn, and cucumber seedlings treated with CWE for 3 weeks. No significant changes were detected in any of the test parameters (Supplemental Tables S1 and S2). The results did not support the hypothesis that altered root development in response to CWE underlies pea root resistance to infection.

Increased pea root infection in the presence of filtered CWE. An alternative explanation for the results is that CWE contains a soluble metabolite triggering a systemic defense response in pea. If so, then filtered CWE would be predicted to inhibit infection as well as unfiltered samples. The results did not support this prediction. In control experiments, filtered CWE added to pouches resulted in no visible changes in growth, development, or morphology in pea seedlings (Fig. 2A). However, lesion development in the presence of filtered CWE was increased from 3 to $100 \%$ of inoculated seedlings (Table 2). Moreover, there was a change in the nature of infection which has not been observed among previous studies $(17,18,21,22,40)$. Instead of a single infection initiated only in the region of elongation and remaining localized at that site (Fig. 1B), lesion development was initiated within each new region of elongation that emerged as growth progressed (Fig. 2B). The root tip region housing the apical meristem and root cap escaped infection; therefore, root growth and development continued as in uninoculated control samples.

Cucumber root infection in the presence of CWE. Some compost extracts have been shown to inhibit disease by direct inhibition of fungal growth (43). Inhibition of spore germination or hyphal growth could account for the observed changes in pea root infection in response to CWE. If so, then a similar effect might be expected to occur in a related fungal pathogen infecting a different plant host. Inoculating cucumber roots with spores of $F$. solani f. sp. cucurbitacae resulted in $100 \%$ infection in the growth pouch assay (Table 3 ). In the presence of CWE, however, unlike in pea inoculated with $F$. solani $\mathrm{f}$. sp. pisi in the presence of CWE, percentage of infection was reduced by only $38 \%$ (Table 3 ).

Fungal growth inhibition in response to CWE. To examine the possibility that a species-specific inhibition of fungal growth is a factor in the divergent results, responses of the Fusarium isolates infecting pea or cucumber to CWE were compared directly using a radial growth assay (43). The diameters of hyphal growth in control plates for both fungi were $30 \pm 1$ and $29 \pm$ $1 \mathrm{~mm}$, respectively, and the results were not significantly different between the two isolates. In the presence of CWE, growth for $F$. solani $\mathrm{f}$. sp. pisi was reduced by $100 \%$ to $0 \mathrm{~mm}$ and $F$. solani $\mathrm{f}$. sp. cucurbitacae was reduced by $97 \%$ to $1 \pm 1 \mathrm{~mm}$. The differences between isolates were not significantly different. The inhibitory effect was lost when CWE was filtered to remove microbial populations: Both isolates exhibited radial growth of $30 \pm$ $1 \mathrm{~mm}$ in the presence of filtered CWE. The results did not support the hypothesis that the differences in protection resulted from differential toxicity of CWE to the fungal isolates under the conditions used.

Border cell trapping on root surfaces in CWE-treated pea but not cucumber. Pea roots grown in pouches with CWE exhibited a distinctive appearance not seen in previous studies: a prominent aggregation of border cells and other material was found to form a sheath surrounding the elongating roots (Fig. 3). The phenotype was evident without microscopic analysis within $24 \mathrm{~h}$ after adding CWE, and remained stable over the period of
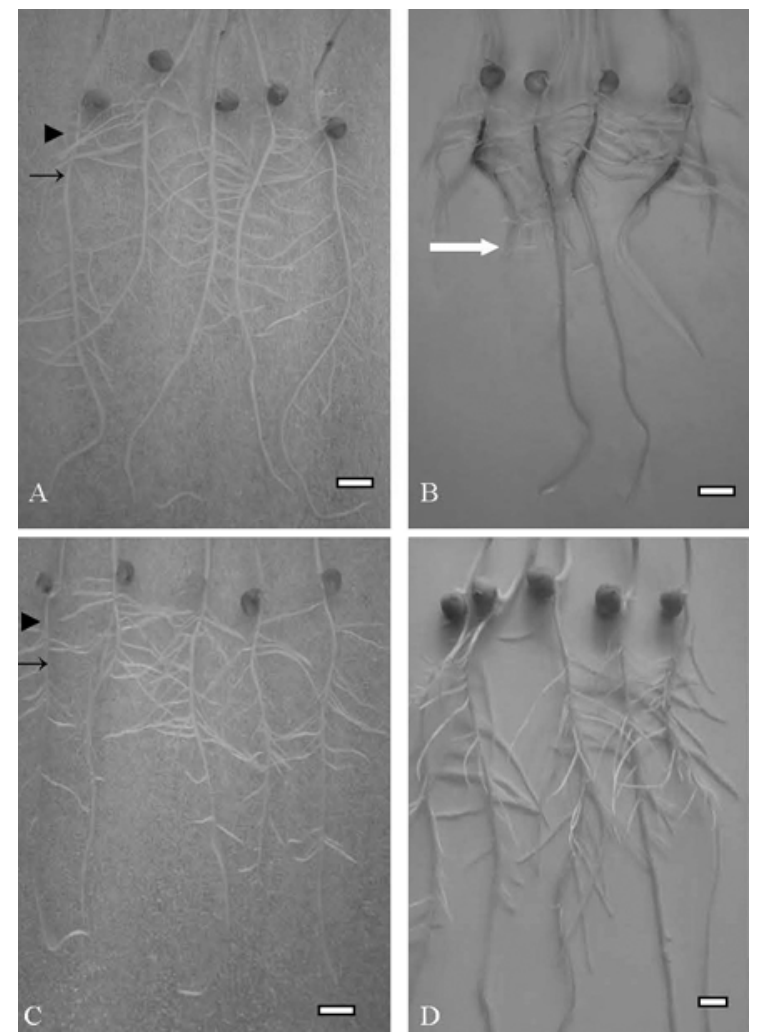

Fig. 1. Impact of compost water extract (CWE) on pea root infection by Fusarium solani. A, Water control. Arrow denotes the site of the root tip at the time of inoculation; black triangle denotes the region of elongation at the time of inoculation. B, Pea roots were inoculated uniformly with $F$. solani spores and maintained in growth pouches at $25^{\circ} \mathrm{C}$ for 13 days. Localized lesion development is evident at the site that was the region of elongation at the time of inoculation. Most roots do not become infected at the root tip containing the root cap and apical meristems; therefore, root growth continues at the same rate as controls. Infection at the tip (white arrow) results in cessation of growth within $24 \mathrm{~h}$. C, Pea roots grown in CWE alone reveal no changes in root growth or development, compared with control samples grown in water. D, Pea roots inoculated uniformly with $F$. solani spores in the presence of CWE develop no lesions. Photos show results 2 weeks after inoculation. Scale bar: $1 \mathrm{~cm}$. 

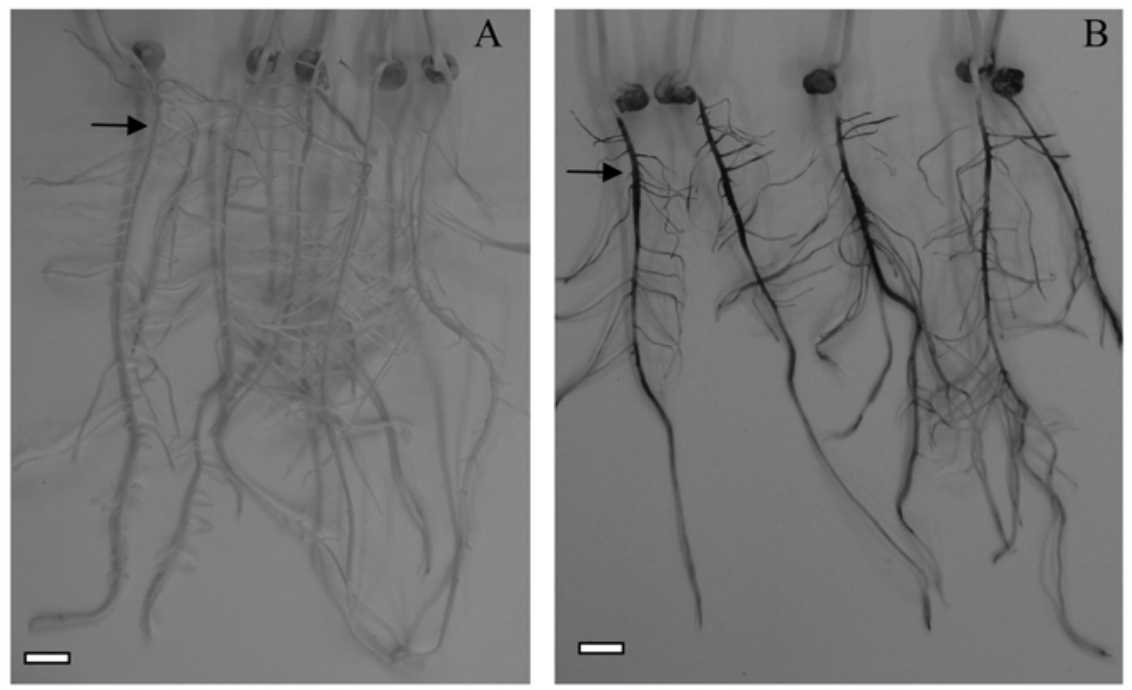

Fig. 2. Impact of filtered compost water extract (CWE) on pea root infection by Fusarium solani. Arrow denotes the site of the root tip at the time of inoculation; black triangle denotes the region of elongation at the time of inoculation. A, Pea roots grown in the presence of filtered CWE and maintained in growth pouches at $25^{\circ} \mathrm{C}$ for 14 days. B, Pea roots grown in the presence of filtered CWE and $F$. solani. Pea roots infected with $F$. solani are blackened due to repetitive infections initiated in the region of elongation but continue to grow because the root tip region escapes infection. Scale bar: $1 \mathrm{~cm}$.

TABLE 2. Impact of filtered compost water extract (CWE) on infection of pea roots by Fusarium solani ${ }^{\mathrm{z}}$

\begin{tabular}{lccc}
\hline & \multicolumn{2}{c}{ Number of seedlings } & \\
\cline { 2 - 3 } Treatment & Noninfected & Infected & Infected (\%) \\
\hline Water & 30 & 0 & $0 \mathrm{a}$ \\
CWE & 30 & 0 & $0 \mathrm{a}$ \\
F. solani & 0 & 30 & $100 \mathrm{c}$ \\
F. solani + CWE & 26 & 4 & $13 \mathrm{~b}$ \\
Filtered CWE & 30 & 0 & $0 \mathrm{a}$ \\
F. solani + filtered CWE & 0 & 30 & $100 \mathrm{c}$ \\
\hline
\end{tabular}

${ }^{\mathrm{z}}$ Values for each treatment reflect results from 30 replicates for each treatment. Percentages of infection with the same letter are not significantly different according to Fisher's exact test $(P<0.05)$.

TABLE 3. Impact of compost water extract (CWE) on infection of cucumber roots by Fusarium solani ${ }^{\mathrm{z}}$

\begin{tabular}{lccc}
\hline & \multicolumn{2}{c}{ Number of seedlings } & \\
\cline { 2 - 3 } Treatment & Noninfected & Infected & Infected $(\%)$ \\
\hline Water & 44 & 6 & $6 \mathrm{a}$ \\
CWE & 46 & 4 & $4 \mathrm{a}$ \\
F. solani & 0 & 50 & $100 \mathrm{c}$ \\
F. solani + CWE & 19 & 31 & $62 \mathrm{~b}$ \\
\hline
\end{tabular}

${ }^{\mathrm{z}}$ Values reflect results from a total of 50 replicates for each treatment. Percentages of infection with the same letter are not significantly different according to Fisher's exact test $(P<0.05)$.

observation. Border cells are produced only by the root cap, and disperse into the environment in response to free water. Even under conditions in which border cells are present on the root cap periphery, the surface of the region of elongation remains free of border cells (Fig. 4A). In the presence of CWE, however, the region of elongation in pea roots instead was covered in a continuous sheath that extended into the regions of lateral root emergence and did not disperse readily in water (Fig. 4B). Microscopic examination revealed that the adhering sheath appeared to consist of border cells interspersed with bacteria. Among single colonies isolated from sheath material dispersed from roots in response to vigorous agitation in water, Acinetobacter spp. (3) were identified as the predominant, culturable bacteria.

In contrast with pea roots, border cells of cucumber roots treated with CWE detached from the cap periphery as the root elongated, and no extended sheath was detected.

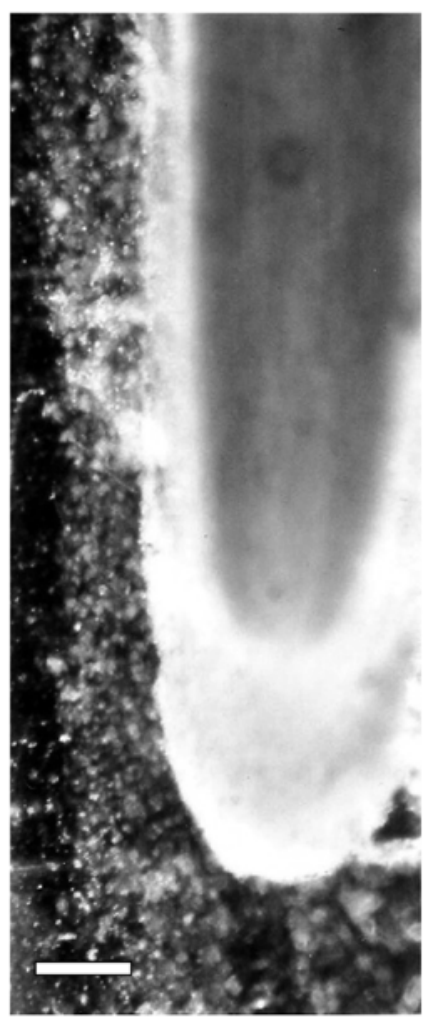

Fig. 3. Persistent mucilaginous sheath of material on pea roots grown in compost water extract. A granular matrix surrounding the root, well past the meristematic region and root cap at the apex, is apparent at low magnification. Scale bar: $5 \mathrm{~mm}$.

\section{DISCUSSION}

We report here that an aerated CWE applied in early development is correlated with protection of pea seedlings against infection by $F$. solani and $P$. pinodella in growth pouches, even under warm, moist conditions highly conducive to root disease development. In cucumber inoculated with $F$. solani, $<40 \%$ reduction in infection frequency occurred in response to CWE, even though CWE was equally inhibitory to mycelial growth of the cucumber and pea pathogens tested. Microscopic examination 

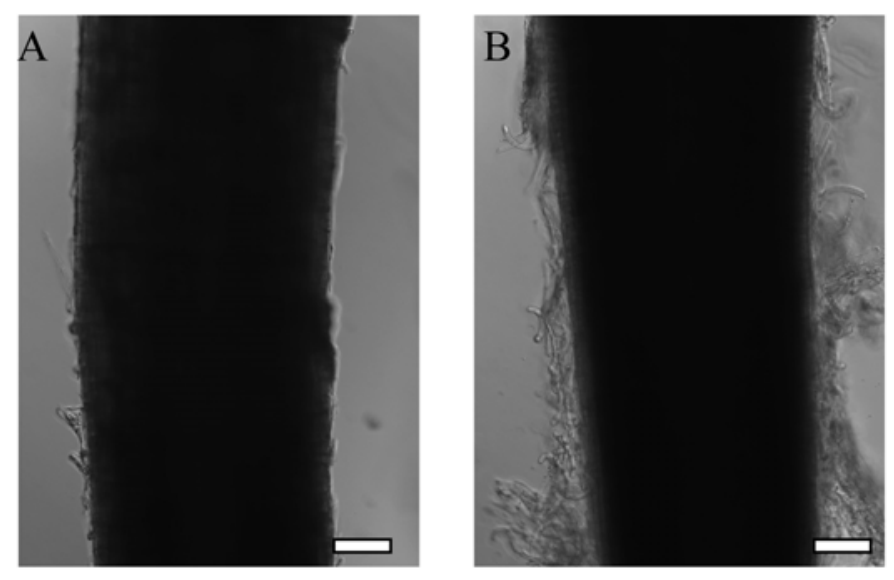

Fig. 4. Border cell sheath extending past the region of elongation on pea roots inoculated with Fusarium solani in the presence of compost water extract (CWE). A, On roots of seedlings grown in water, a few border cells can be seen near the surface. $\mathbf{B}$, On roots grown in CWE, a continuous sheath of border cells is evident within $24 \mathrm{~h}$ after inoculation, and the aggregate remains adhered to the root surface after 14 days (shown here) in moist growth pouches maintained at $25^{\circ} \mathrm{C}$. Scale bar: $1 \mathrm{~mm}$.

revealed a marked difference in the response of cucumber and pea seedlings to CWE that has not been reported in previous studies: The protection against infection in pea roots was correlated with the presence of an extended sheath of border cells interspersed with bacteria covering the primary site of susceptibility to $F$. solani and $P$. pinodella - the region of elongation. Border cells are programmed to separate from root tips, and comprise the bulk of organic matter released from young seedlings $(11,21)$. Recent studies have revealed that border cells function in defense of roots in a manner parallel to that of mammalian white blood cells, which form mucilaginous extracellular traps comprised of extracellular DNA and antimicrobial proteins $(22,40)$. Border cells provide a highly effective defense that protects the apical region housing the root meristems from infection and injury and also may be important for the maintenance of beneficial rhizosphere organisms including protozoa (39). Border cells of most species disperse into the environment as the root elongates, leaving the surface of the newly synthesized region of elongation accessible to colonization. It will be of interest in future studies to examine the possibility that the presence or absence of this sheath on roots treated with CWE underlies the fact that regions of elongation in pea but not cucumber were protected from infection.

In this study, the border cells within extended sheaths on CWEtreated roots were found to be coaggregated with bacterial populations in which Acinetobacter spp. were predominant. This genus is widely distributed in soil, water, sewage, rhizosphere, and compost $(6,15)$. Acinetobacter spp. can be selected from soil and water under conditions similar to those used for preparation of the test CWE, including the use of vigorously aerated mineral-rich medium maintained for 24 to $48 \mathrm{~h}$ at 30 to $40^{\circ} \mathrm{C}$ and $\mathrm{pH} 5.5$ (3). Recent studies suggest potential for these bacteria as a biological control agent for control of Ralstonia solanacaerum wilt on tomato (44). Remarkably, some Acinetobacter spp. trigger coaggregation with other microbial species $(27,37)$. It will be of interest to explore the possibility that microbial coaggregation properties interface with the "trapping" capacity of border cells, and that this plays a role in the observed protection of susceptible regions of pea roots by an extended border cell sheath. If this early rhizosphere modification can be shown to remain stable and exert protection long enough to harvest a crop, then further studies to define why it happens in pea but not cucumber, and is so effective in sand but not soil, will be warranted.

We described the use of a rapid, reproducible assay to measure direct effects of compost extracts on root structure and function in early stages of development. Water and mineral uptake, as well as susceptibility of plants to soilborne pathogens and symbionts, are processes controlled primarily by specialized tissues within the apical regions of young roots $(1,10,17,21)$. Root-rhizosphere associations established early in development may play a key role in plant health $(9,35)$. Our results suggest that it may be possible to use the growth pouch assay to discern differences in effectiveness of specific compost preparations on crop species early in seedling development to evaluate possible underlying mechanisms for the differences and, thereby, assist in engineering plant growth media that optimize the benefits of compost applications.

\section{ACKNOWLEDGMENTS}

We thank the Department of Soil, Water and Environmental Sciences, College of Agriculture and Life Sciences, University of Arizona, and the National Science Foundation (NSF number1032339) for their support.

\section{LITERATURE CITED}

1. Aiken, R. M., and Smucker, A. J. M. 1996. Root system regulation of whole plant growth. Annu. Rev. Phytopathol. 34:325-346.

2. Bauer, W. D. 1981. Infection of legumes by rhizobia. Annu. Rev. Plant Physiol. 32:407-449.

3. Baumann P. 1968. Isolation of Acinetobacter from soil and water. J. Bacteriol. 96:39-42.

4. Carballo, T., Gil, M. V., Calvo, L. F., and Moran, A. 2009. The influence of aeration system, temperature, and compost origin on the phytotoxicity of compost tea. Compost Sci. Util. 17:127-139.

5. Chen, M. H., and Nelson, E. B. 2008. Seed-colonizing microbes from municipal biosolids compost suppress Pythium ultimum damping-off on different plant species. Phytopathology 98:1012-1018.

6. Choudhary, D. K. 2011. First preliminary report on isolation and characterization of novel Acinetobacter spp. in casing soil used for cultivation of button mushroom, Agaricus bisporus (Lange) Imbach. Int. J. Microbiol. article 790285.

7. Clapp, C. E., Shenker, M., Hayes, M. H. B., Liu, R., Cline, V. W., Palazzo, A. J., and Gen, Y. 2008. Microsystems for rapid evaluation of plant growth response to organic amendments. Soil Sci. 173:342-349.

8. Craft, C. M., and Nelson, E. B. 1996. Microbial properties of composts that suppress damping-off and root rot of creeping bentgrass caused by Pythium graminicola. Appl. Environ. Microbiol. 62:1550-1557.

9. Cummings, J. A., Miles, C. A., and du Toit, L. J. 2009. Greenhouse evaluation of seed and drench treatments for organic management of soilborne pathogens of spinach. Plant Dis. 93:1281-1929.

10. Curl, E. A., and Truelove, B. 1986. The Rhizosphere. Advanced Series in Agricultural Sciences, Vol. 15. Springer-Verlag, Berlin-Heidelberg-New York, Tokyo.

11. Curlango-Rivera, G., and Hawes, M. C. 2010. Root tips moving through soil: an intrinsic vulnerability. Plant Signal. Behav. 6:1-2.

12. Elmer, W. H., and McGovern, R. J. 2004. Efficacy of integrating biologicals with fungicides for the suppression of Fusarium wilt of cyclamen. Crop Prot. 23:909-914.

13. Franz, E., and van Bruggen, A. H. C. 2008. Ecology of E. coli O157:H7 and Salmonella enterica in the primary vegetable production chain. Crit. Rev. Microbiol. 34:143-161.

14. Gareau, B. J., and DuPuis, E. M. 2009. From public to private global environmental governance: lessons from the Montreal Protocol's stalled methyl bromide phase-out. Environ. Plan. 41:2305-2323.

15. Gopalakrishnan, S., Humayun, P., Kiran, B. K., Kannan, I. G. K., Vidya, M. S., Deepthi, K., and Rupela, O. 2011. Evaluation of bacteria isolated from rice rhizosphere for biological control of charcoal rot of sorghum caused by Macrophomina phaseolina (Tassi) Gold. World J. Microbiol. Biotechnol. 27:1313-1321.

16. Goud, J.-K., Termorshuizen, A. J., Blok, W. J., and van Bruggen, A. H. C. 2004. Long-term effect of biological soil disinfestation on Verticillium wilt. Plant Dis. 88:688-694.

17. Gunawardena, U., and Hawes, M. C. 2002. Tissue specific localization of root infection by fungal pathogens: Role of root border cells. Mol. PlantMicrobe Interact. 15:1128-1136.

18. Gunawardena, U., Rodriguez, M., Straney, D., Romeo, J. T., VanEtten, H. D., and Hawes, M. C. 2005. Tissue-specific localization of pea root infection by Nectria haematococca. Mechanisms and consequences. Plant Physiol. 137:1-12.

19. Han, D. Y., Coplin, D. L., Bauer, W. D., and Hoitink, H. A. J. 2000. A rapid bioassay for screening rhizosphere microorganisms for their ability to induce systemic resistance. Phytopathology 90:327-332. 
20. Hargreaves, J. C., Adl, M. S., and Warman, P. R. 2009. The effects of municipal solid waste compost and compost tea on mineral element uptake and fruit quality of strawberries. Compost Sci. Util. 17:85-94.

21. Hawes, M. C., Brigham, L. A., Wen, F., Woo, H. H., and Zhu, Y. 1998. Function of root border cells in plant health: pioneers in the rhizosphere. Annu. Rev. Phytopathol. 36:311-327.

22. Hawes, M. C., Curlango-Rivera, G., Xiong, Z., and Kessler, J. O. 2012. Roles of root border cells in plant defense and regulation of rhizosphere microbial populations by extracellular trapping. Plant Soil. 355:1-16.

23. Kavroulakis, N., Ntougias S., Besi, M. I., Katsou, P., Damaskinou, A., Ehaliotis, C., Zervakis, G. I., and Papadopoulou, K. K. 2010. Antagonistic bacteria of composted agro-industrial residues exhibit antibiosis against soil-borne fungal plant pathogens and protection of tomato plants from Fusarium oxysporum f. sp. radicis-lycopersici. Plant Soil 333:233-247.

24. Kim, Y. C., Leveau, J., McSpadden Gardener, B. B., Pierson, E. A., Pierson, L. S., III, and Ryu, C. 2011. The multifactorial basis for plant health promotion by plant-associated bacteria. J. Bacteriol. 77:2113-2121.

25. Litterick, A. M., Harrier, L., Wallace, P., Watson, C. A., and Wood, M. 2004. The role of uncomposted materials, composts, manures, and compost extracts in reducing pest and disease incidence and severity in sustainable temperate agricultural and horticultural crop production-a review. Crit. Rev. Plant Sci. 23:453-479.

26. Mahdi, S. S., Hassan, G. I., Samoon, S. A., Rather, H. A., Showkat, A. D., and Zehra, B. 2010. Bio-fertilizers in organic agriculture. J. Phytopathol. 2:42-54.

27. Malik, A., Sakamoto, M., Ono, T., and Kakii, K. 2003. Coaggregation between Acinetobacter johnsonii S35 and Microbacterium esteraromaticum strains isolated from sewage activated sludge. J. Biosci. Bioeng. 96:10-15.

28. Martin, J. P. 1950. Use of acid, rose bengal, and streptomycin in the plate method for estimating soil fungi. Soil Sci. 69:215-232.

29. Noble, R., and Coventry, E. 2005. Suppression of soil-borne plant diseases with composts: a review. Biocontrol Sci. Technol. 15:3-20.

30. O’Donnell, K., Sutton, D. A., Fothergill, A., McCarthy, D., Rinaldi, M. G., Brandt, M. E., Zhang, N., and Geiser, D. M. 2008. Molecular phylogenetic diversity, multilocus haplotype nomenclature, and in vitro antifungal resistance within the Fusarium solani species complex. J. Clin. Microbiol. 46:2477-2490.

31. Olanya, O. M., and Larkin, R. P. 2006. Efficacy of essential oils and biopesticides on Phytophthora infestans suppression in laboratory and growth chamber studies. Biocontrol Sci. Technol. 16:901-917.

32. Pharand, B., Carisse, O., and Benhamou, N. 2002. Cytological aspects of compost-mediated induced resistance against Fusarium crown and root rot in tomato. Phytopathology 92:424-438.

33. Pinton, R., Varanini, Z., and Nanipieri, P. 2007. The Rhizosphere: Biochemistry and Organic Substances at the Soil-Plant Interface. Marcel Dekker, Inc. New York, Basel.

34. Sang, M. K., and Kim, K. D. 2011. Biocontrol activity and primed systemic resistance by compost water extracts against anthracnoses of pepper and cucumber. Phytopathology 101:732-740.

35. Scheuerell, S. J., Sullivan D. M., and Mahafee, W. F. 2005. Suppression of seedling damping-off caused by Pythium ultimum, P. irregulare and Rhizoctonia solani in container media amended with a diverse range of Pacific Northwest compost sources. Phytopathology 95:306-315.

36. Shane, M. W., McCully, M. E., Canny, M. J., Pate, J. S., Huang, C., Ngo, H., and Lambers, H. 2010. Seasonal water relations of Lyginia barbata (Southern rush) in relation to root xylem development and summer dormancy of root apices. New Phytol. 185:1025-1037.

37. Simoes, L. C., Simoes, M., and Vieria, M. J. 2008. Intergeneric coaggregation among drinking water bacteria: evidence of a role for Acinetobacter calcoaceticus as a bridging bacterium. Appl. Environ. Microbiol. 74:1259.

38. Singh, P. K., and Vias, D. 2009. Biocontrol of plant diseases and sustainable agriculture. Proc. Natl. Acad. Sci. India Sect. B Biol. Sci. 79:110-128.

39. Somasundaram, S., Bonkowski, M., and Iijima, M. 2008. Functional role of mucilage-border cells: a complex facilitating protozoan effects on plant growth. Plant Prod. Sci. 11:344-351.

40. Wen, F., White, G. J., VanEtten, H. D., Xiong, Z., and Hawes, M. C. 2009. Extracellular DNA is required for root tip resistance to fungal infection. Plant Physiol. 151:820-829.

41. Weng, Z., Bartelson, R., Gowda, S., Hilf, M. E., Dawson, W. O., Galbraith, D. W., and Xiong, Z. 2007. Persistent infection and promiscuous recombination of multiple genotypes of an RNA virus within a single host generate extensive diversity. PLoS ONE 2:e917.

42. Wilson, K. 2001. Preparation of genomic DNA from bacteria. Pages 241245 in: Current Protocols of Molecular Biology. F. M. Ausubel and R. Brent, eds. Greene Publishing and Wiley Interscience, NY.

43. Xu, D., Raza, W., Yu, G., Zhao, Q, Shen, Q., and Huang, Q. 2012. Phytotoxicity analysis of extracts from compost and their ability to inhibit soil-borne pathogenic fungi and reduce root-knot nematodes. World J. Microbiol. Biotechnol. 28:1193-1201.

44. Xue, A., Chen, Y., Li, S., Ding, G., Guo, D., and Guo, J. 2009. Evaluation of the strains of Acinetobacter and Enterobacter as potential biocontrol agents against Ralstonia wilt of tomato. Biol. Control 48:252-258. 